\section{EREM 75/1}

Journal of Environmental Research Engineering and Management

Vol. 75 / No. 1 / 2019

pp. 7-12

DOI 10.5755/j01.erem.75.1.2086
Environmental Impact of No-Tillage Farming

Received 2018/08
Accepted after revision 2018/10

\title{
Environmental Impact of No-Tillage Farming
}

\section{Davut Karayel}

Akdeniz University, Faculty of Agriculture, Department of Agricultural Machinery and Technologies Engineering, Antalya, Turkey

\section{Egidijus Šarauskis}

Vytautas Magnus University, Institute of Agricultural Engineering and Safety, Studentu 15A, LT-53362,

Akademija, Kaunas r., Lithuania

Corresponding author: dkarayel@akdeniz.edu.tr

Davut Karayel, Akdeniz University, Faculty of Agriculture, Department of Agricultural Machinery and Technologies

Engineering, Antalya, Turkey

No-tillage seeding applications that conserve natural resources such as soil and water and decrease the cost of inputs for agricultural production have become an increasingly applied method to conventional tillage systems including ploughing. Traditional tillage systems in the subtropics and tropic regions and with intensive tillage applications will lead to soil degradation and a decrease in crop production efficiency. This will also lead to poverty and emigration of farmers from rural areas. If we want to give the farmers a chance to continue farming and if sustainable agricultural production is to be ensured, then land use and management methods should be revised and improved, and new or modern cultivation systems should be applied.

No tillage is the practice of never soil tilling before seeding operation. The essence of no-tillage is providing the soil surface covered with stubble residue.

No-tillage systems have remarkable impacts on crop production and environment:

they reduce erosion (wind and water), thereby reducing environmental pollution and, most importantly, protecting water resources;

they reduce carbon emissions;

they contribute to increasing biodiversity in the soil;

they provide agricultural production using less energy than conventional tillage, and essentially the conservation tillage or conservation agriculture practices contribute to sustainable development.

Keywords: environment, erosion, no-tillage, conservation tillage, conservation agriculture. 


\section{Introduction}

Increasing energy costs and increasing erosion with intensive soil tillage operations have led farmers and researchers to alternative soil tillage methods. The aim of alternative tillage systems is to keep the field surface covered with at least $30 \%$ of plant residue by reducing the density of soil tillage. Conservation tillage methods consist of strip-tillage, mulch-tillage, plant-tillage (tillage during the seeding operation), minimum tillage, no-tillage and zero tillage. Secondary tillage equipment can be used for cultivation after sowing in no-tillage. However, in zero tillage, no soil treatment is performed during the whole vegetation period.

No-tillage or direct seeding refer to generic names describing the seeding of seeds into untilled soil previously specifically to form a 'seed bed'. The term of no-tillage is used in the United States and Canada (North of America); meanwhile, the terms of direct-seeding or direct-sowing are used in England (and most of European countries) to describe the same process. The basis of putting seeds into untilled soils is very old. Ancient Egyptians used to create a hole in untilled soil with a stick putting seeds into the hole and then closing the hole again by pressing the sides together with one foot. When the weed-controlling chemicals paraquat and disquat were released in 1960s, the modern concept of no-tillage was born (Baker et al., 2002).

Research on modern methods of no-tillage agriculture in the USA began in earnest during the 1960s. But in Turkey and Middle East, it began in 1980s and attracted continuing academic interest. Researchers soon demonstrated the soil conservation benefits of no-tillage, and economic aspects were later elucidated. Nevertheless, there was limited interest at a practical level, and deep tillage predominated throughout the 1980s.

Conservation tillage and no-tillage methods offer various benefits. These benefits and advantages of these tillage systems are summarised as follows: more natural life, less carbon emissions and air pollution, saving on time, decrease in agricultural machinery wear, lower labour requirements, fuel saving, higher efficiency in agricultural productivity, better surface water quality, lower soil erosion, increase in the moisture retention capacity of the soil, reduced soil compaction and reduced soil crust formation.

No-tillage offers a way to address some agronomic and environmental risks presented by conventional tillage, and to improve the overall environmental quality. Birkas et al. (2008) identified the main environmental risk factors of soil tillage: soil compaction, clodding or smearing/puddling or dust formation, inducing water and wind erosion, soil crust formation, decreased organic content, increased carbon dioxide emission, and destruction of earthworm habitats. The

\section{Table 1}

Environmental impacts of planting method on humid soils (Birkas et al., 2008)

\begin{tabular}{l|c|c|c}
\hline $\begin{array}{c}\text { Environmental } \\
\text { risk factors }\end{array}$ & $\begin{array}{c}\text { No } \\
\text { tillage }\end{array}$ & $\begin{array}{c}\text { Strip } \\
\text { tillage }\end{array}$ & $\begin{array}{c}\text { Conventional } \\
\text { tillage }\end{array}$ \\
\hline 1 & 2 & 3 & 4 \\
\hline Soil compaction & $0^{*}$ & - & 0 \\
\hline Water/wind erosion & - & - & + \\
\hline Stubble residues & - & - & + \\
\hline Moisture loss & - & - & + \\
\hline Environmental risk & less & least & great \\
\hline
\end{tabular}

* Impact on environmental risk: - (alleviation); 0 (neutral); + (increase) at the given soil moisture content, and for the respective planting process; - and 0 indicate a lessened risk; + signifies a greater risk.

\section{Table 2}

Environmental impacts of planting methods on dry soils (Birkas et al., 2008)

\begin{tabular}{l|c|c|c}
\hline $\begin{array}{c}\text { Environmental } \\
\text { risk factors }\end{array}$ & $\begin{array}{c}\text { No } \\
\text { tillage }\end{array}$ & $\begin{array}{c}\text { Strip } \\
\text { tillage }\end{array}$ & $\begin{array}{c}\text { Conventional } \\
\text { tillage }\end{array}$ \\
\hline 1 & 2 & 3 & 4 \\
\hline Soil compaction & $-{ }^{*}$ & - & 0 \\
\hline Water/wind erosion & - & - & + \\
\hline Stubble residues & - & - & + \\
\hline Moisture loss & - & - & + \\
\hline Environmental risk & least & least & great \\
\hline
\end{tabular}

* Impact on environmental risk: - (alleviation); 0 (neutral); + (increase) 
Table 3

Environmental risk of planting methods on wet soil (Birkas et al., 2008)

\begin{tabular}{l|c|c|c}
\hline $\begin{array}{c}\text { Environmental } \\
\text { risk factors }\end{array}$ & $\begin{array}{c}\text { No } \\
\text { tillage }\end{array}$ & $\begin{array}{c}\text { Strip } \\
\text { tillage }\end{array}$ & $\begin{array}{c}\text { Conventional } \\
\text { tillage }\end{array}$ \\
\hline Soil compaction & 2 & 3 & 4 \\
\hline Water/wind erosion & - & 0 & + \\
\hline Stubble residues & - & - & + \\
\hline Moisture loss & 0 & 0 & + \\
\hline Environmental risk & less & less & great \\
\hline
\end{tabular}

* Impact on environmental risk: - (alleviation); 0 (neutral);

+ (increase)

environmental effects of the main risk factors are summarised in Tables 1 to 3. Tillage or other operations are considered environmentally benign when there are no significant adverse effects during adoption and when the result of operation is likely to fulfil soil conservation and environmental criteria.

\section{Effect of No-Tillage on Soil Properties}

Structural properties of aggregates on the soil surface such as distribution of dimensions, stability, strength, and wettability determine an erosive effect of water/ wind erosion on the soil. Knowledge of aggregate structural properties is particularly considerable in semiarid regions getting low rain, high evaporation, and variable agricultural crop production coupled with conventional tillage (include intensive tillage operations) and fallow sensitivity of the soil to water/wind erosion.

Blanco et al. (2009) revealed that no-tillage farming increased soil aggregate resistance against raindrops and water repellence over ploughed systems, particularly at the surface of soil (soil surface to a depth of $2.5 \mathrm{~cm}$ ). The required kinetic energy of raindrops to disperse aggregates (at the size of 4.7 to $8.0 \mathrm{~mm}$ ) from no-tillage soils stabilised at water potential (matric potential) of 30 and 155,000 Pa. It was 2-7 times higher than that required for ploughed soils. The penetration time of drops in soil aggregates from no-till fields was between 4 and 7 times higher compared with that in ploughed fields. Reduced till was less beneficial than no-till but was more beneficial than conventionally tilled soils.

A no-tillage system induced increase in organic carbon concentration of soil partly explained the improvement in aggregate properties. The organic carbon concentration of soil was higher in no-tillage methods than in conventionally tilled fields. Kinetic energy of raindrops required for aggregate disintegration increased positively, while aggregate wettability decreased with the increase in soil organic carbon concentration. Soils rich in organic carbon most likely provided organic binding agents to stabilise aggregates. Soil organic carbon compounds also imparted slight hydrophobic characteristics, reducing aggregate slaking and the amount of eroded soil. Aggregate wettability was positively correlated with wet (moist) aggregate stability. Aggregates in no-till soils were equally strong or slightly weaker when dry compared with those in ploughed soils.

Karlen et al. (1994) evaluated several soil quality indicators such as soil aggregate properties (characteristics), penetration resistance and bulk density of soil, population of earthworms, water content, respiration, microbial biomass content, and testing factors of soil ( $\mathrm{pH}$, phosphorus, potassium, calcium, magnesium, total nitrate, total carbon, $\mathrm{NH}_{4}-\mathrm{N}$ and $\mathrm{NO}_{3}-\mathrm{N}$ ). The effect of doubling, removing, or maintaining crop residues was determined using these indicators for 10 years in a no-tillage system. Higher total $\mathrm{C}$ concentrations and higher microbial activity (determined by carbon dioxide supply) were obtained with the residue treatments (double and normal residue level). Plant residues were removed for 10 years and earthworm populations were substantially lower than double or normal residue treatments.

\section{Effect of No-Tillage on Carbon Dioxide Emissions}

Emission is combustion of fossil fuels takes place by the mixing of the gases into the atmosphere. Atmospheric gases create the greenhouse effect. 
Greenhouse gases keep the sun rays reflected from the earth and cause the temperature to increase. Greenhouse gases are $\mathrm{CO}_{2}, \mathrm{CH}_{4}, \mathrm{~N}_{2} \mathrm{O}, \mathrm{PFC}, \mathrm{HFC}$ and $\mathrm{SF}_{6}$ according to the United Nations Framework Convention on Climate Change (UNFCC).

Carbon dioxide emissions are caused by transportation, industrial activities, energy production, wastes and agricultural activities. The $\mathrm{CO}_{2}$ (equivalent) values of total greenhouse gas emissions were approximately $70 \%$ from energy production, 13\% from industrial operations and $7 \%$ from agricultural activities in Turkey in 2016 (TUIK, 2017).

Soil is the most important natural resource for agricultural activities and the centre of the nutrient (especially carbon and nitrogen) cycling. Soil includes more carbon than the biosphere and the atmosphere. Cultivating the soil results in losses of organic matter with the carbon dioxide release into the atmosphere. These releases contribute to the greenhouse effect. Soils are not well-known sources of the carbon dioxide release into the atmosphere, but they are actually among the most important carbon dioxide emission sources (Mello and Raij, 2006).

Many scientific researches on soil carbon dioxide emissions from agricultural soils have been carried out. Most of them have focused on the roles of climate change, mainly temperature and rainfall, on soil respiration. However, tillage also has an important influence on soil carbon dioxide emissions. Lifeng et al. (2007) observed $\mathrm{CO}_{2}$ release on cultivated lands with a winter wheat and maize rotation. The seedbed was prepared before seeding with three tillage methods: conventional tillage method, reduced tillage method (rotary till) and no-tillage method. Soil carbon dioxide emission was generally higher in conventional tillage $\left(11.30 \mathrm{~g} \mathrm{CO}_{2} / \mathrm{m}^{2}\right.$ per day) than in no-tillage $(7.99 \mathrm{~g}$ $\mathrm{CO}_{2} / \mathrm{m}^{2}$ per day) and reduced tillage (rotary till) (9.63 $\mathrm{g} \mathrm{CO}_{2} / \mathrm{m}^{2}$ per day). The highest $\mathrm{CO}_{2}$ emissions were measured with the conventional and rotary tillage applications (no statistical difference between conventional and rotary tillage). The tillage operations (conventional or reduced-rotary) for seedbed preparation before seeding result in a faster physical release of carbon dioxide.

\section{Effect of No-Tillage on Erosion}

Erosion is the removal of soils particles from land surface, deposition and transportation of the soil particles by the action of wind or water. Tillage methods are among the most effective factors on soil erosion (wind or water).

Ploughing is an significant application in tillage systems, especially for primary tillage for seedbed preparation or weed control. According to results of scientific research on tillage, that this type of soil tillage was found out inconvenient. Bare soil (uncovered) obtained after ploughing in a slope terrain is a unprotected soil. Researchers have found out that soil losses caused by heavy rains falling on an uncovered soil surface can reach tens of tons of lost soil per hectare only in one year (Table 4). The best part of soil can be carried away by erosion flows.

\section{Table 4}

Stubble residues - soil losses relations (Aykas et al., 2010)

\begin{tabular}{c|c|c|c}
\hline $\begin{array}{c}\text { Stubble residues } \\
(\mathrm{t} / \mathrm{ha})\end{array}$ & $\begin{array}{c}\text { Surface flow } \\
(\%)\end{array}$ & $\begin{array}{c}\text { Infiltration } \\
(\%)\end{array}$ & $\begin{array}{c}\text { Soil losses } \\
(\mathrm{t} / \mathrm{ha})\end{array}$ \\
\hline 1 & 2 & 3 & 4 \\
\hline 0.00 & 45.0 & 54 & 13.00 \\
\hline 0.63 & 40.0 & 60 & 7.50 \\
\hline 1.25 & 25.0 & 74 & 2.50 \\
\hline 2.50 & 0.5 & 99 & 0.75 \\
\hline 5.00 & 0.1 & 99 & 0.00 \\
\hline 10.00 & 0.0 & 100 & 0.00 \\
\hline
\end{tabular}

Soils carried by erosion fill rivers, lakes and water reservoirs. Soil particles reduce the volume for water in reservoirs or rivers. The capacity of water reservoirs is reduced and the treatment of muddy water for settlement supplies becomes more difficult and expensive (Derpsch and Moriya, 1998; Mello and Raij, 2006).

The majority (86\%) of Turkey's territory is under threat of erosion (including $63 \%$ of the soil under severe and very severe erosion threat). Thus, the area affected by erosion is 66.9 million hectares. The causes of erosion are different, but two most important reasons are water and wind erosion in Middle East and Turkey. Wind 
and rain drift fertile lands and transport them to reservoir lakes, stream beds and seas. Soil carried from the field with a river in Turkey is 7 times greater than in the United States, 17 times greater than in European countries and 22 times greater than in African countries. Because of erosion, 90 million tons of plant nutrients, 500 million tons of agricultural land, and 1.4 billion tons of fertile topsoil from the surface of the entire country are lost per year. These lost lands are equivalent to a land of $25 \mathrm{~cm}$ thick and 400 thousand hectares wide (Aykas et al., 2010).

Soil losses in agricultural fields in Latin America are estimated to be about 10-60 t/ha per year (Steiner, 1998; Derpsch and Moriya, 1998). Soil lost on average per ha/year in conventional agriculture is $23 \mathrm{t}$, while only $0.53 \mathrm{t} /$ ha per year are lost when the no-tillage method used. The difference between conventional tillage and no-tillage is $22.47 \mathrm{t} /$ ha per year (Venialgo, 1996, cited by Karlen, 2006).

\section{Effect of No-Tillage on Water Quality}

Water resources can be polluted for various reasons. Pollutants that cause pollution of water resources in general are sediments that are formed as a result of erosion, nitrates and phosphate fertilisers used in agricultural activities, animal wastes, bacteria, organic substances and pesticides. The pollution of underground water is the first to be contaminated with nitrates. Contamination of underground water as well as contamination of underground water by nitrates is a serious environmental pollution. Tillage methods of soil are among the most effective factors on the amount of nutrient surface flow and infiltration into soil.

More than $75 \%$ of phosphorus in the surface water is adhered to soil particles. The remaining amount (approximately 25\%) is soluble phosphorus. Reducing soil erosion is the most efficient way to increase phosphorus pollution by surface run-off. Direct seeding (no-tillage farming) reduces total phosphorus losses. Dissolved phosphorus losses in no-tillage systems are generally higher than conventional soil treatments. Phosphorous fertilisers should be placed near seed or deep-banded for decreasing the phosphorus-induced losses.
Nitrogen in the nitrate form can easily move with soil water. Therefore, water and nitrate can interfere with ground water and cause an environmental threat. The main sources of nitrogen in the soil include biological fixation by legumes, commercial fertilisers, animal manure, soil organic matter and plant residues.

More macro pores form in the fields applying no-tillage systems than in the fields applying conventional tillage systems. Macro pores allow more water to penetrate soil faster. This leads to concerns that no-tillage agriculture can lead to further nitrate infiltration into ground water. However, in studies comparing the effect of tillage systems on nitrogen infiltration, there is no evidence that there is more nitrate activity in no-tillage agriculture. Regardless of the soil tillage methods, more attention must be paid to nitrate infiltration in areas near water resources for the human consumption, especially those with sandy soils above ground water (Devlin and Barnes, 2009).

Sharpley and Smith (1994) compared the impact of no-tillage (direct seeding) and conventional tillage (mouldboard plough) on surface and groundwater quality for wheat growing. Annual surface run-off was similar for both tillage methods (from 6 to $15 \mathrm{~cm}$ ). The no-tillage method reduced sediment, nitrogen and phosphorus loss by an average of $95 \%, 75 \%$ and $70 \%$, respectively. A high level of dissolved phosphorus (maximum $3.1 \mathrm{mg}$ per litre) in surface water, and nitrate-nitrogen in underground water resource (max. $26 \mathrm{mg}$ per litre) were determined in no-tillage methods. The results of the research point out that more elaborated fertiliser application and timing should be considered in the management of no-tillage methods.

\section{Conclusions}

The awareness of the significance of protecting soil and water (in general terms, the environment) has been increasing rapidly in recent years. As a result, especially academics, agricultural engineers and conscious farmers have started to reduce tillage operations or to move no-tillage farming. Reduced tillage or no-tillage systems are important techniques for energy conservation at every stage of agricultural 
production and important applications for environmental protection.

According to results of some studies, it was declared that the recent drought beginning after 2000 in the Eastern Mediterranean region, which comprises Turkey, Syria, Palestine, Jordan, Israel and Lebanon, is likely the worst drought of the past 9 centuries. During the past decade, dry years with longer droughty periods have become increasingly frequent in this region. This may encourage growers to adopt production

\section{References}

A.N. Sharpley, S.J. Smith. 1994. Wheat tillage and water quality in the southern plains, Soil and Tillage Research, 1994, 30 (1), 33-48. https://doi.org/10.1016/0167-1987(94)90149-X

C.J. Baker, K.E. Saxton, W.R. Ritchie, 2002. No-tillage Seeding: Science and Practice. New York: CAB International, 2002.

D.L. Devlin, P.L. Barnes, 2009. Impacts of No-till on Water Quality [online], [cited 25th January 2016]. Available at: http://www. ksre.ksu.edu/library/crpsl2/mf2907.pdf

D.L. Karlen, N.C. Wollenhaupt, D.C. Erbach, E.C. Berry, J.B Swan, N.S. Eash, J.L. Jordahl. 1994. Crop residue effects on soil quality following 10-years of no-till corn. Soil and Tillage Research, 1994, 31 (2-3), 149-167. https://doi.org/10.1016/01671987(94)90077-9

E. Aykas, E. Çakır, H. Yalçın, B. Okur, Y. Nemli, A. Çelik. 2010. Koruyucu Toprak İşleme, Doğrudan Ekim ve Türkiye'deki Uygulamaları, VII. Technical Congress of Agricultural Engineering, 11-15 June 2010, Ankara, Turkey.

H. Blanco, M.M. Mikha, J.G. Benjamin, L.R. Stone, A.J. Schlegel, D.J. Lyon, M.F. Vigil, P.W. Stahlman, 2009. Regional study of no-till impacts on near surface aggregate properties that influences soil erodibility. Soil Sci. Soc. Am. J., 2009, 73, 1361-1368. https://doi.org/10.2136/sssaj2008.0401

H. Lifeng, C. Fu, L. Hongwen, Z. Xuemin, L. Lin, L. Wenying, N.J. Kuhn, 2007. Carbon dioxide emissions after application of dif- practices that are adapted to these extreme climatic conditions. No-till technologies under extensive farming conditions can be easily learned and profitably implemented within a reasonable time period. Some of the environmental risk factors of soil tillage such as soil compaction, clodding or smearing/ puddling or dust formation, water and wind erosion, decreased organic content, increased carbon dioxide emission, and destruction of earthworm habitats can be decreased using no-tillage farming systems.

ferent tillage systems for loam in Northern China. International Seminar on Enhancing the Extension of Conservation Agriculture Techniques in Asia and the Pacific Zhengzhou, Henan, China

I. Mello, B. Van Raij 2006. No-till for sustainable agriculture in Brazil. Proc. World Assoc. Soil and Water Conserv., P. 49-57

K.G. Steiner, 1998. Conserving Natural Resources and Enhancing Food Security by Adopting No-Tillage. An assessment of the Potential for No-Tillage for Soil-Conserving Production Systems in Various Agro-Ecological Zones of Africa. TöB F-5e, GTZ, Eschborn, Germany.

M. Birkás, M. Jolánkai, A. Stingli, 2008. Experiences in No-till Farming in Hungary. No-till Farming Systems. Bangkok: World Association of Soil and Water Conservation. Bangkok

N. Venialgo, 1996: IN: D.L. Karlen, 2006. Istro Info. A Publication of the International Soil Tillage Research Organization [online], [cited 25th January 2018]. Available at: http://iworx5.webxtra. net/ istroorg/download/ISTRO\%20INFO\%200ctober\%202006. pdf

R. Derpsch, K. Moriya, 1998. Implications of no-tillage versus soil preparation on sustainability of agricultural production. Advances in Geoecology, 1998, 2, 1179- 1186

TUIK, 2017. Turkish Statistical Institute Datas [online], [cited 25th April 2018]. Available at: http://www.tuik.gov.tr 